\title{
Constructing a Life on the Northern Frontier: E.A.C. Olive of Cooktown
}

\author{
Belinda McKay
}

Repeated 'boom and bust' phenomena have characterised the history of Queensland as a colony and state. In terms of infrastructure and cultural institutions, this has led to significant discontinuities: vital strategic centres of colonial power, such as Cooktown, now languish in relative obscurity and the role of their inhabitants as authors and agents of colonialism receives little attention. This study investigates the life of an early inhabitant of Cooktown, E.A.C. Olive, in the context of his location on Australia's northern frontier.

The paper is in four parts. The first part looks at Cooktown's establishment as a northern foothold of colonial rule; the second considers E.A.C. Olive's public life as a businessman on the northern frontier; the third discusses Olive's domestic life; and the fourth investigates his naturalist pursuits. Analysis of E.A.C. Olive's commercial, domestic and scientific activities reveals that he and his family were dependent in complex, ongoing and unacknowledged ways on Aboriginal people in the period following the frontier wars, when the colony of Queensland was reinforcing its territorial conquests.

\section{Cooktown and the northern frontier}

Cooktown is the northernmost town on the east coast of Australia: in some important respects, it still marks the northern frontier of effectual colonisation in Queensland. Cape York Peninsula is one of the few areas in Queensland where the Indigenous population outnumbers whites; with the exception of mining, white economic activity is marginally profitable; and, most importantly, its Indigenous people (along with Torres Strait Islanders) have in recent years launched powerful legal challenges which have undermined the Australian people's belief in the legitimacy of colonisation. Hope Vale, the Aboriginal community located across the river from Cooktown, was the first land in Queensland to be returned to Indigenous ownership. ${ }^{1}$

One of the earliest extended contacts between Europeans and Aborigines on the east coast of Australia took place between 17 June and 5 August 1770, when Captain Cook repaired the damaged Endeavour on the banks of a river that he named after his ship; the Guugu Yimithirr name for the place was 'Charco'. The outcome of this contact - of which, of course, only Cook's side is recorded in writing - was mixed. According to Cook's journal, interaction with local people was peaceable overall, but a hostile exchange followed his failure to share turtle meat. ${ }^{2}$ The expedition's scientists, Sir Joseph Banks and Daniel Solander, recorded over 180 'new' botanical species in the area, and were the first white men to record sightings of kangaroos, possums and other native animals. Cook's visit left a lasting impact on the environment, too, most notably 
by the release of the progenitors of the so-called 'Captain Cooker' feral pigs, which continue to wreak considerable environmental damage on Cape York Peninsula.

Despite a number of subsequent land and sea based expeditions to the peninsula, colonisation of the north proceeded slowly until 1872, when William Hann was commissioned by the Queensland Government to 'ascertain as far north as the $14^{\text {th }}$ parallel of latitude, the character of the country and its mineral resources, with a view to future settlement and occupation. ${ }^{3}$ Hann found gold on a river he named the Palmer after Queensland's Colonial Secretary and later Premier, Arthur Palmer. The following year, James Venture Mulligan’s party brought back 102 ounces of gold from the Palmer River: it was this find which precipitated the invasion of the far north by triggering one of Australia's last major gold rushes.

The first diggers reached the Palmer River by overland routes, but on 25 October 1873, the steamer Leichhardt arrived with members of the Gold Fields Department, white and Native Police, road builders and 79 miners (some of whom were Chinese) to establish a port at 'Cook's Harbour' and establish a track to the goldfields. According to the eye-witness account of William Webb, this advance party was surprised by Aborigines before dawn on 5 November 1873, at the site thereafter known as Battle Camp: no whites were wounded, but the Aborigines were pursued, and many were trapped and shot. Five days later, this same party shot more Aborigines at Emu (now Kavanagh) Creek. Of this latter incident, Webb remarked: 'A lot of BLACKS were shot while we were at this camp. I do not know why, as they had not interfered with us.' 4 Shooting Aborigines on sight became standard practice on the northern frontier, aided and abetted by the finding of a government inquiry that the miners were justified in their actions at Emu Creek.

On the Palmer River, slaughter of Aborigines, combined with environmental destruction by an army of heavily armed miners and officials, quickly took a toll on the local people, who responded by spearing cattle and horses for food, and by attacking the miners at vulnerable points on the track to the diggings. ${ }^{5}$ Hell's Gate, a common spot for ambushes, came to symbolise all the fears of the colonisers: when Donald and Hugh McQuarrie were killed there, the Cooktown Courier trumpeted that they were 'run down like paddymelons by a merciless mob of infuriated cannibals. ${ }^{6}$ Cape York Peninsula's reputation for being the home of 'unusually hostile and intractable' Aborigines had begun with the ill-fated Kennedy expedition. ${ }^{7}$ According to Edward Palmer, '[i]n no district of Queensland have the blacks shown themselves more hostile to the settlers than in the Peninsula.' 8 Unproven assertions that the northern tribes were cannibals generated further terror, masking ruthless self-interest by providing miners with a convenient moral justification for extermination.

Noel Loos concludes from a detailed study of the deaths of settlers and their employees that 'more than twice as many people were reported killed by Aborigines in the Cooktown-Palmer District [as] on all other North Queensland frontier mining fields'. ${ }^{9}$ The Aboriginal death rate through resistance and starvation was, as Loos emphasises, 'immeasurably greater' than that of the invaders. ${ }^{10}$ Local newspapers, protected by tacit government support for their stance, explicitly advocated the extermination of Aboriginal people. On 24 June 1874, the Cooktown Herald blazoned: 
When savages are pitted against civilization they must go to the wall; it is the fate of their race. Much as we may deplore the necessity for such a state of things, it is absolutely necessary in order that the onward march of civilization may not be arrested by the antagonism of the aboriginals.

However, despite such resolve on the part of the colonisers, the Indigenous people sustained guerrilla warfare in the Cooktown-Palmer River area for several decades. Only in Cooktown itself could the invaders feel safe from attack.

In 'Cook's Town', as the port was originally known, the rapidity and volume of the invasion had quickly displaced Aboriginal tenure of the area close to the mouth of the Endeavour River. Miners, officials and entrepreneurs arrived in droves by ship and established a tent town in their wake. Estimates of the population in 1874 - the year that the settlement was officially named Cooktown - vary wildly: while some sources put it as high as 40,000, it is more likely that there were in fact only about 150 'permanent' inhabitants. ${ }^{11}$ Estimates that 35,000 people had passed through the town en route to and from the gold fields by 1876 may give a more reliable indication of the nature of this frontier port.

With such a volume of traffic, permanent infrastructure quickly replaced the tents. Wharves and hotels were erected first, followed by substantial and often imposing examples of Queensland colonial architecture. The original wooden Court House is gone, but the brick and stone bank buildings (originally the Bank of North Queensland and the Bank of Queensland) can still be seen in Charlotte Street. ${ }^{12}$ The former Roman Catholic convent, now the James Cook Historical Museum, is the town's largest building; set on the hillside behind the main street, it has a commanding view of the river and the north shore from its balcony. Many buildings were destroyed in the 1907 and 1949 cyclones and the 1919 fire, and others have been demolished after falling into disrepair. Only three of the legendary 'hundreds' of pubs, for example, still occupy their original sites: the Sovereign, the West Coast and the Cooktown (formerly Commercial) Hotels. However, indestructible granite kerbs and channels built by Cornish stonemasons still flank a thin bitumen and dirt strip that forms the main street, Charlotte Street. These surviving traces of an impressive infrastructure eloquently demonstrate that not all the new arrivals headed for the gold fields; indeed, there were rich pickings in Cooktown for entrepreneurs.

\section{E.A.C. Olive and the colonial 'aristocracy of commerce'}

One such arrival was E.A.C. Olive, who established a business during the early days of the Palmer River gold rush and remained in Cooktown until his death in 1921. Spencer Browne, editor of the Cooktown Herald in the 1870s, records in his memoirs that Olive was one of the leading members of Cooktown's 'aristocracy of commerce'. He 'was about $6 \mathrm{ft}$. 4 in. in his stockings, had served in a good British regiment, and was a cultured man and scholarly'. ${ }^{13}$

Edmund Abraham Cumberbatch Olive was born in Hellingly, Sussex, in 1844. His father, the Reverend John Olive, Vicar of Hellingly in Sussex, was the Oxford-educated descendant of a family of cloth dyers from Frome, Somerset who had made money and raised their social status to that of gentlemen as a result of the industrial revolution. On 
the maternal side, Olive was connected to the Chaloners of Yorkshire, who descended from British and European aristocracy. His mother's second cousin, Admiral Thomas Chaloner, C.B., was involved in the British Navy's suppression of the slave trade in Africa. It is indeed ironic, then, that E.A.C. Olive migrated to a part of the world where Aboriginal people were slaughtered with the support of government policy, and where both Aborigines and Pacific Islanders were subjected to forms of slavery.

Anecdotes recalled by his descendants suggest that Olive came to the colonies in disgrace following a sexual indiscretion. His death certificate states that in 1921 he had been in the Australian colonies for 47 years (i.e., since 1874), but he certainly arrived in Australia prior to this date, since the death of Edmund James Olive, the illegitimate oneyear-old son of Edmund Olive and Grace Neil, is recorded at Mt Perry, in the District of Gayndah, in 1873. ${ }^{14}$ Another child, Edmund Olive, was born in Ravenswood in January 1874, at which time E.A.C. Olive gave his occupation as a 'carrier.' Carting supplies was a lucrative occupation on the goldfields, and his movement from Ravenswood to Cooktown suggests that Olive was part of the frenzied mass of miners and suppliers who deserted the Ravenswood and Etheridge diggings for the Palmer fields on receiving word of Mulligan's discovery.

E.A.C. Olive arrived in Cooktown in 1874 or 1875, at the peak of the Palmer gold rush. When a daughter, Mabel, was born there on 26 October 1875, E.A.C. Olive described himself as a 'storekeeper'. ${ }^{15}$ In 1876, the same year that he formalised his union with Grace Neil, he established a business as an auctioneer and horse and cattle salesman. Subsequently, he developed some lucrative sidelines as a stock, station, land, customs, insurance, forwarding and general commission agent, and general broker. He ran this wide-ranging business from a 'yard and mart' (known as the Central Auction Mart) in Charlotte Street, next to the Commercial Hotel. ${ }^{16}$ Olive also invested in property in the area; for example, with fellow Cooktown auctioneer F.J.W. Beardmore, he established King's Plains Station on the road to Byerstown, one of the Palmer goldfield towns. ${ }^{17}$ Business boomed for a few years, during which Cooktown - renowned as the 'Queen of the North' and the 'Canton of the South' - supported a substantial population of European and Chinese merchants and functioned as Australia's gateway to New Guinea and Asia. It seemed that the town would become the springboard for further colonisation of Cape York Peninsula.

Despite its early promise, however, Cooktown's economic bubble burst almost as quickly as it began. The alluvial gold of the Palmer River was depleted by 1876, and by 1886 the diggings were virtually abandoned. New gold discoveries elsewhere in the north led to the establishment of Port Douglas and Cairns, which soon eclipsed Cooktown in importance. However, a core of Cooktown businessmen, E.A.C. Olive amongst them, believed - at least for a few years - in the town's capacity to prosper with new industries when gold declined. Initially, the establishment of Cairns must have seemed to be a good omen - another step in the consolidation of the white conquest of the north. E.A.C. Olive and F.J.W. Beardmore were the agents for one of the earliest pieces of infrastructure in Cairns, the Q.S.S. jetty. At the first land sales in Cairns, on 15 February 1877, E.A.C. Olive acquired property in Cairns, and on 4 February 1879, he took up land near Lamb Ridge, but later forfeited it due to non-compliance with residential clauses. ${ }^{18}$ Forgoing his Cairns investments was a poor business decision given the subsequent histories of the 
two towns, and E.A.C. Olive may have regretted his faith in Cooktown's future relatively quickly.

By 1881, E.A.C. Olive was in fact making repeated reference in business letters to the depressed economy of Cooktown. On 30 December, 1881, he informed Charles Patching in Maytown: 'No business whatever doing here.' Two months later, on 24 February 1882, he lamented to G. Ryle of Herberton: 'Everything still very dull here and I am afraid will remain so for some time to come.' By the middle of 1882, however, property values were rising. In September 1882, E.A.C. Olive sold some of his properties for $£ 1000$; he believed that he might have held out for $£ 1200$ for the properties 'but I did not care to let the matter hang on too long as I have already lost ch[ances?] for want of dollars'. The increase in property values appears to have been related to the prospect of government investment in infrastructure. On 16 June 1882 E.A.C. Olive had written to D.H. Dalrymple: 'Property of all sorts is going up in price and if the long expected Railway was to commence it would doub[le] the value. ${ }^{19}$ This pinning of hopes on what Spencer Browne aptly terms 'the long-deferred renaissance,20 is a repeated pattern in Cooktown; it can still be observed today in the expectation that a boom in tourism will follow the completion of a bitumen road from Cairns to Cooktown. The 'long expected Railway,' which was intended to connect Cooktown and Maytown, was begun in 1884, but never reached its destination: the railway bridge at Laura, completed in 1891, became the end of the line. The railway generated high expectations but little lasting prosperity: after running in fits and starts for over 70 years, its permanent closure in 1961 marked Cooktown's lowest point as a colonial enterprise.

In 1886, accepting that the gold rush was over, the town attempted to lure newcomers by advertising itself as 'a thrifty place of much promise':

Population nearly 3000, of which 480 are Chinese. It is a place of considerable trade, and contains a court-house, town hall, Masonic hall, hospital, with bonded stores, custom-house and accommodations, public and private, for extensive business. Also three churches, public and denominational school, with two newspapers and several local social clubs. ... Cooktown is a place of call for vessels trading to and from New Guinea and other islands. A railway is under construction to connect Cooktown to the Palace diggings. The chief industry of the district at present is agriculture, in which sugar-growing has a prominent place. There are beche-de-mere [sic] and pearl shell fisheries, and it is altogether reckoned a thrifty place of much promise. Returns for 1886 show 1338 acres under cultivation; horses, 2601; cattle, 43,800; pigs, 1638; imports for 1886, £96,034; exports, $£ 86,873$; and it may be called the port of the Palmer River diggings. Coal has been found in the district. As a proof of the activity of the people, and the importance of the place, it may be mentioned that three large iron bridges are in process of erection. These and the railroad will give great impetus to trade and traffic. ${ }^{21}$

In this glowing report, no mention is made of Cooktown's precarious position at the northern margins of colonisation; despite its vigorous efforts to establish the infrastructure and institutions which would mark it out as a successful example of white conquest, it was still on the frontier. 
As gold-related income declined, E.A.C. Olive took on new enterprises. His business letters reveal that he supplied equipment to the bêche-de-mer industry, which peaked in North Queensland between 1881 and 1884, but which was so notorious for its kidnapping and ill-treatment of Aboriginal and Islander labourers, including young children, that Cooktown officials had considered prosecutions under Imperial anti-slavery legislation. ${ }^{22}$ E.A.C. Olive also had agricultural and other farming interests: at various times, he and his family raised cattle, operated a dairy, owned a peanut farm on the Annan River, and sold cut flowers from their own gardens. Olive was reputed to be a wealthy man, but most of these activities - like gold mining - followed a boom and bust pattern, and descendants claim that Olive lost most of his money in the early 1890s as a result of the depression and bank crises. Olive's apparent prosperity was probably built partly on the decline of the town. As an auctioneer and agent, he sold land, businesses, and goods and chattels for departing residents; when the departures increased, it is likely that he acquired more goods than it was possible to sell. On the death in 1958 of Olive's son and business successor, Carlton Chaloner Olive (known to intimates as 'Bando'), the Olive warehouse was full of unsold - indeed, unsellable - goods, to which the residents of Cooktown helped themselves.

E.A.C. Olive also participated in the public life of colonial Cooktown through involvement with local government. He was Shire Clerk of the Daintree Divisional Board (later Shire) from 1885, and when the Daintree and Hann Shires amalgamated in 1919 he was elected Shire Clerk and Valuer of the newly created Shire of Cook at a salary of $£ 4.0 .0$ per week. ${ }^{23}$ The 'jack-of-all-trade duties' of the position of clerk in north Queensland boards, according to Geoffrey Bolton, included 'rate collecting, sanitary inspection, vermin destruction, and overseership of roads. ${ }^{24}$ It is ironic that as the economic self-sufficiency of Cooktown declined, more and more money flowed from the government for spending on public works - a clear indication of the strategic importance of this northern outpost for the colonial government's claim to control its gazetted territory. As Shire Clerk, Olive participated in planning and implementing Cooktown's property polices and infrastructural development during the period of peak government expenditure on the town in the 1880s and early 1890s: he was involved with the extension of the railway and the construction of the railway wharves, the bridges over the Annan and the Endeavour Rivers, the new hospital, the Cook Monument, various municipal buildings and the Botanic Gardens. In other ways, too, E.A.C. Olive contributed to public life: he was, for instance, a member of the Chamber of Commerce and Secretary of the Cooktown Hospital Board.

In his public life, then, E.A.C. Olive exemplifies the capitalist activity and civic mindedness that were essential to the establishment, maintenance and expansion of colonial rule in Queensland following the frontier wars. Without the existence of Cooktown, the mining frontier on the Palmer River would have been over-extended and unable to survive Aboriginal resistance. Whether or not they participated directly in killing Indigenous people, colonists like Olive aided the advance of the frontier and made fortunes in the process. As much as the miners, they were motivated by 'Queensland's god': greed. ${ }^{25}$ After the initial bloody push, the colonisers dedicated themselves to the project of erasing Aboriginal sovereignty and culture. For at least twenty years after its establishment, frontier wars continued on land and sea in the vicinity of Cooktown, but the tiny port dedicated itself to the recreation of British institutions and infrastructure: the 
machinery of white culture and colonial government gradually replaced the carbine as the means of sending 'savages' 'to the wall' in the interests of the 'onward march of civilization'. When Aboriginal people entered Cooktown, they did so as racialised inferiors, deprived of access to colonial power structures, dispossessed of land, and separated from their extended family groups.

\section{'Mount Olive'}

While Aboriginal land was the basis of the wealth and power of the colonisers, the labour of Aboriginal people became essential to the maintenance of the colonial enterprise. In the case of E.A.C. Olive, the dependence of the coloniser on the colonised most clearly manifests itself in the domestic sphere.

As Cooktown's gold-based economy declined, E.A.C. Olive turned increasingly to the cultivation of personal interests, centred on his domestic life. On arrival in Cooktown, the Olives - like everybody else - lived in a tent. Later Olive accommodated his rapidly increasing family in a cottage in Walker Street, but in 1881 he acquired 19 acres of land on a ridge of Mt Cook: in an appropriately patriarchal flourish from a white man who eventually fathered at least 15 children, he named the site 'Mount Olive.' In 1882 he built a large timber home on this site, which overlooks Cooktown, the Endeavour River and Grassy Hill. ${ }^{26}$ The house was built on bloodwood blocks, eight feet off the ground, with verandahs on three sides and ceilings 11 feet high: it was built to last, but was dismantled after sustaining serious damage in the 1949 cyclone.

The gardens of Mt Olive were described by a journalist in the 1950s as 'the fulfilment of a botanist's dream'. ${ }^{27}$ On the hillside below the house, the Olive sons - probably with the assistance of Aboriginal workers - constructed a series of terraces out of local grey granite, using bottles as filler. The driveway sweeping up to the house was lined with coconut palms, and elsewhere there were river palms and a native fernery. E.A.C. Olive also planted longan and lychee trees from plants brought to Cooktown by early Chinese residents, as well as many varieties of mangoes; these plantings probably represent an experiment aimed at determining which fruits could be grown commercially in Cooktown. These gardens were established at the same time as the Botanical Gardens by botanist, Anthony W. Persieh, with whom E.A.C. Olive was in close contact as Shire Clerk. The planting of exotics was continued by E.A.C. Olive's son, Herbert Lawrence ('Bertie') Olive, whose botanical interests had developed during some years spent as a cane inspector for C.S.R. at Lautoka in Fiji. ${ }^{28}$ Herbert L. Olive planted crotons around the Cook Monument in town, and probably introduced the many varieties of hibiscus, frangipani and bougainvillea on Mt Olive: even after the dismantling of the home, he kept up the gardens of Mt Olive with the assistance of local people such as Bob Cook, Cec Murdoch and Royce Lee. ${ }^{29}$ The philosophy promulgated in the late nineteenth century by the Acclimatisation Society, whose aim was to 'acclimatise' exotic flora and fauna for both commercial and ornamental purposes, is evident in this garden.

Domestic life at Mt Olive was rigid in its observance of such matters as dining etiquette and strict in its enforcement of what the parents deemed to be appropriate behaviour: Grace Olive whipped her daughters if they breached her standards! ${ }^{30}$ But the Olives were eccentric in their flouting of other conventions. E.A.C. Olive and Grace Neil did not marry until 1876, when they had already had three children: the two surviving 
illegitimate children were legitimised in 1900. In matters of dress, too, E.A.C. Olive was highly unconventional: perhaps in adherence to principles of the Rational Dress movement, he refused to wear a suit in the tropics, favouring instead loose-fitting, cool shirts and trousers. In a 1909 photograph of the members of Cooktown's Chamber of Commerce, the elderly Olive is the only one not wearing a suit. ${ }^{31}$ E.A.C. Olive was eccentric in other aspects of his behaviour too. An atheist, he enjoyed instigating vigorous arguments with local and visiting ministers of religion, and refused to erect headstones in the cemetery for family members (several children and his wife died before him). Although he wished his own body to be burnt on a funeral pyre, he is buried in an unmarked grave amidst the elaborate and encomiastic monuments to his contemporaries.

After the move to Mt Olive, the family's relations with the town were characterised by a certain aloofness. Olive does not appear to have participated much in Cooktown's social activities, but had a reputation for living 'the high life' at Mt Olive, presumably because he regularly entertained visiting dignitaries and ships' captains, sending his carriage to collect them when they landed. ${ }^{32}$ There was, however, an exception to the distance he imposed between the town and his domestic life: he appears to have placed considerable importance on cordial relations with the Chinese community, taking his children and grandchildren to Chinese homes to celebrate Chinese New Year. According to his granddaughter, Grace (Olive) Worrall, he spoke Chinese and interpreted for Customs. Carlton C. Olive kept up this warm relationship, and when the last Chinese inhabitants left Cooktown he took it upon himself to tend and renovate the contents of the Joss House. Rene Hallam recounts that:

Mr Olive salvaged all the abandoned Joss House. There were no Chinese left in the town. He spent many hours gilding and repainting the carvings and the Gods.... He had a very comprehensive collection and all visitors to Cooktown made it a point to view his Museum. ${ }^{33}$

A reconstruction of the interior of the Joss House, containing many of the items retrieved by Carlton C. Olive, is now on display in the James Cook Museum.

The Olive children were educated at Mt Olive by English tutors and governesses, not at the local schools, until the depression of the 1890s. They enjoyed a high degree of freedom of movement and freedom from conventions, which applied - unusually - to the girls as well as the boys. In The Tin Scratchers, Ion L. Idriess describes how, when walking through the bush near Cooktown in 1912, he was startled by a rider who came up quietly behind him and then, with a yell, spurred on her horse:

I leapt aside right smart as a whirlwind galloped by throwing behind a peal of girlish laughter. With panting heart I swore at the vanishing horseman - a girl! Clad in pants with shirt-sleeves rolled up - I'd never seen a girl in pants before! Not those pants. Breathing heavily, I slouched back for the discarded swag, gazing after her flying through the timber. She took a log in her stride, an exultant yell as girl and horse leapt through the air. The devil of a rider! ...

Clatter of hooves away ahead, and a little mob of horses burst through the timber with a younger girl flying at their heels. The horses wheeled roguishly but, with a yell, my devil rider was at their flank driving them galloping all out for a big house 
up on the hill, a large bungalow set in a lovely garden of bamboos and shrubs and trees.

These were the Olive youngsters, rounding up the horses. What wonderful specimens of womanhood that team of girls of Olive the auctioneer was to grow into! ${ }^{34}$

The riders were probably Gladys and Doris, two of Olive's younger daughters. Gladys, in particular, was renowned for her riding and shooting skills.

As well as the Olives' own five surviving children (eight more were to survive infancy), the household included an Aboriginal child known as Nellie, who had her own room at Mt Olive and probably received some education with the white children. According to Olive descendants, Nellie had been 'rescued' by Grace Neil when her mother was shot during a conflict in Cooktown's early days. Evidence that Nellie was treated as if she were (at least in some respects) a member of the Olive family should not obscure the fact that she was stolen: Nellie was taken from her own people and treated by the Olives as if she were their property. Such terminology is not the recent revelation of a more enlightened era: in 1880, the editor of The Queenslander deplored the fact that Aboriginal children were 'forcibly stolen'. ${ }^{35}$ The circumstances of Nellie's 'rescue', moreover, suggest that E.A.C. Olive may have been directly involved in the frontier wars.

At least some of the Olive children felt that not only Nellie, but also other Aboriginal children at Mt Olive, were in some sense their brothers and sisters. According to Olive's youngest son, John Henry 'Jack' Olive, the white children were given 'Aboriginal names' and some of them spoke an Aboriginal language. One of the Aboriginal children, Sammy Olive, certainly received an education along with the white children: he spoke excellent English, and was literate. ${ }^{36}$ Emma Bradford (Olive) Hope surprised people in Mossman by having her black 'brother' Sammy Olive dine with her family when he visited her in Mossman in the 1930s: however, her son Neil Hope recalls that Sammy did not spend the night with them. I have been unable to trace descendants of the Aboriginal people at Mt Olive to find out how they characterised their relationship with the Olives. However, while forms of companionship and affection existed, the extreme power imbalance between white and Aboriginal people, both at Mt Olive and in the wider society, means that any sense of kinship can have existed only within narrow parameters, and that the two groups attached different meanings to - and had different expectations of - inter-racial family analogies.

What is certain is that Aboriginal labour formed the basis of Mt Olive's domestic economy, and enabled the white family to enjoy the kind of economic and social freedoms outlined above. Olive's right-hand man was Billy Olive, who lived with his wife Dora and children Sammy and Daisy in the 'blacks' camp' near the cow yard at the foot of Mt Olive. Sammy Olive in turn took over his father's role: in the 1930s he lived with his wife Rosie (McLean) Olive in a caretaker's hut near the main entrance to Mt Olive. ${ }^{37}$ A dairy - probably using Aboriginal labour - was located on the hill behind the Olive bungalow, and Aboriginal women also worked in the house as domestic servants. In front of the house were springs, where 'the gins did the washing. ${ }^{38}$ Large boulders in front of the house were used by Aboriginal women for laying out the silverware for 
cleaning, a weekly ritual in which the Olive children and grandchildren sometimes participated.

The precise nature and extent of Mt Olive's reliance on Aboriginal labour is unclear, but the testimony of Olive descendants suggests that a number of Aboriginal people worked for E.A.C. and Grace Olive as house servants and agricultural and farm labourers in the late nineteenth and early twentieth centuries. As a result of Aboriginal labour (and Chinese cooks), Grace Olive, according to her granddaughter Dorothy Adams, 'did nothing except what she wanted to do [for example, needlework and bee-keeping] ... no hard yakka'. Dorothy Adams also commented that the Aborigines at Mt Olive were 'very loyal': they 'would see anyone coming along the road and would watch them and watch them.' ${ }^{39}$ The loyalty of the Aboriginal workers is the moral of a number of stories about life at Mt Olive, the implication being that the Olives were good people who inspired such sentiments. While E.A.C. Olive may have treated his Aboriginal workers better than a good many of his contemporaries, his wealth and lifestyle in Cooktown were built on the founding act of dispossession of Aboriginal people, and later by their labour. Although (white people's) anecdotal and photographic evidence suggests that bonds of mutual respect and warmth existed at Mt Olive, the relationships existed within a context of extreme inequality of power: to be white conferred privileges - above all, the right to own land - while to be black was to be dispossessed and forced to work for the white invaders.

In return for their labour, Aboriginal people probably received basic supplies and some education for the children, along with a degree of protection from exposure to worse circumstances, such as being forced into the bêche-de-mer industry in the early days, or being forcibly removed to a reserve after the advent of the Aboriginals Protection Act in 1897. For instance, E.A.C. Olive is said to have intervened to prevent the removal of Billy and Sammy Olive. ${ }^{40}$ Mt Olive's location on the edge (just within the boundary) of Cooktown, a town determined to be white, must have produced tensions. In 1885, for instance, just three years after the establishment of Mt Olive, the town passed a by-law banning Aboriginal people from its boundaries at night, ${ }^{41}$ a regulation which clearly represents only the surface level of hostility to Aborigines entering 'white' space. The Mt Olive 'blacks' camp', remarkably, survived within the town boundary until at least the 1930s. ${ }^{42}$

\section{'A cultured man and scholarly'}

E.A.C. Olive's scholarly interests also benefited from the contribution of Aboriginal people. Towards the end of the century, when Cooktown's economy had slowed, E.A.C. Olive increasingly devoted himself to that popular pursuit of the cultured nineteenth century English gentleman, naturalism, and achieved a reputation as 'a careful and accurate field-naturalist'. ${ }^{43}$ The work of naturalists played an important role in the colonial venture: in a process which has some affinities with the compilation of the Domesday Book by William the Conqueror, the 'discovery' and 'naming' of native flora and fauna played an integral role in the stocktaking of new territories and their contents. In the late nineteenth century, the flora and fauna of Cape York Peninsula were little known, due to successful resistance to colonisation by Aboriginal people, but were believed to include many unique and 'undiscovered' species, and many species that 
resembled those found in Papua but not elsewhere in Australia. Robinson and Laverock argued in 1900 that

it would appear that the portion of Australia between Cape York and the mouth of the Herbert River and east of the watershed should be regarded as a well-marked division belonging quite as much to the Papuan as to the Australian faunal region. ${ }^{44}$

Cape York Peninsula represented one of the last great frontiers for naturalism.

Cooktown's location made it of great interest to natural scientists, whose modus operandi did not necessarily include field trips. Rather, they depended on specimens and field notes supplied by amateur or professional collectors. In turn, collectors like E.A.C. Olive relied heavily - like Australia's white 'explorers' - on the knowledge and assistance of Aboriginal people. Billy Olive, and his son Sammy later on, not only helped E.A.C. Olive to locate specimens, but also taught him and his children about bush craft: in the words of a granddaughter of E.A.C. Olive, 'the blacks showed him everything. ${ }^{45}$ Collectors often complain that their work is under-acknowledged by scientists, but several species were named after E.A.C. Olive, whereas the contribution to natural science of Aboriginal people like Billy Olive has never been recognised by white Australia. An incident which occurred on Hann's expedition provides an example of how Aboriginal people contributed to naturalism. Robert Logan Jack recounts that Jerry, the Aboriginal member of Hann's expedition,

described a climbing kangaroo which he had seen in the Cardwell district, and showed Hann and Tate trees bearing the marks of the ascent of some such animal. Although they did not see the animal itself, which was then unknown to science, its subsequent discovery places beyond doubt the accuracy of Jerry's information and description. $^{46}$

It was frequently on the basis of descriptions such as this that amateur and professional naturalists sought and 'discovered' species previously unknown to Western science.

Collection could have a significant environmental impact, particularly when commercial interests were involved. The lucrative trade in orchids devastated one of Cooktown's best-known native plants: the Cooktown Orchid (Dendrobium bigibbum var. phalaenopsis), Queensland's floral emblem. The hills surrounding Cooktown were once densely covered with purple orchid blossoms during the winter, but today few wild orchids remain. E.A.C. Olive's involvement in this trade is revealed in a letter dated 29 September 1882: 'I got some nice orchids last Sunday and will get more tomorrow.' ${ }^{, 9}$ Similarly, collectors killed native animals and removed eggs in the pursuit of scientific kudos and commercial profit: the rarer the specimen, the greater the incentive. In a letter to Alfred J. North, Ornithologist at the Australian Museum, E.A.C. Olive casually describes having shot 'fully two dozen' female and immature specimens of the Eastern Bower-Bird (Chlamydodera orientalis), and also discusses his habit of collecting their eggs from October to December. ${ }^{48}$ Wastage was a problem, as specimens would often be damaged during collection, preservation or transportation. To support his interest in naturalism, E.A.C. Olive constructed specialised facilities at Mt Olive, including 
collection tanks and a workshop for preparing and preserving specimens through such techniques as taxidermy, drying and immersion in formalin.

Naturalism was an interest developed within the domestic context of Mt Olive. In one of his letters to Alfred J. North, Olive describes how White-Eyebrowed Caterpillar-Eaters (Lalage leucomela is now known as the Varied Triller) 'frequent the trees in the garden about my cottage, feeding on caterpillars and the fruit of a native fig-tree. The branches of one of these trees overhangs my verandah, so I am able to watch them within a distance of three yards. ${ }^{49}$ Mt Olive, located on a ridge of Mt Cook (431 m.) and close to the Annan and Endeavour Rivers, was also a good starting point for the excursions to nearby areas of dense vegetation with undisturbed flora and fauna: for example, E.A.C. Olive sent Alfred J. North a specimen of a Newton's Bower-Bird (Prionodura newtonia, now known as the Golden Bower-Bird) that he had obtained near the summit of Mt Cook on 28 May 1899. This was an important find in terms of the scientific frontier, because it was then - and remains - the most northerly recording of the species. ${ }^{50}$

Along with the Aboriginal guides, Olive's sons and daughters participated in some of these field trips. Olive accumulated impressive collections of various native fauna, as well as sending many specimens to Australian, European and American taxonomists, collectors and museums. The Australian Museum, for example, received many specimens collected by E.A.C. Olive in Cooktown, Bellenden Ker and New Guinea, including reptiles; bird skins, nests and eggs; fish; insects and arthropods; molluscs; and a young agile-wallaby (Macropus agilis). Several species were named for him, including a bird, Turnix olivii (Buff-Breasted Button-Quail), and a gecko, Gymnodactylus olivii. ${ }^{51}$ Turnix olivii is one of the rarest of Australian birds; since E.A.C. Olive collected the first specimen in 1899, it has been recorded only at eight sites, all between Iron Range and Mareeba, and has never been photographed. ${ }^{52}$

While E.A.C. Olive appears to have developed naturalism primarily for personal rather than commercial reasons, his son Edmund Olive became a professional naturalist who collected specimens in the Northern Territory, New Guinea and throughout northern Queensland for sale to private collectors. Edmund Olive was also employed by professional ornithologists to collect specimens and write field-notes: for example, in 1899 he collected specimens in the Bellenden Ker area on behalf of Herbert C. Robinson and W.S. Laverock. On this expedition, Edmund Olive camped for over a week at an altitude of over 4,000 feet; he ascended Bellenden Ker three times and also collected on nearby Mt Sapphiri. He sent Robinson and Laverock a significant collection of specimens (including items from the Olive Collection) and detailed field-notes, which provided the basis for their refutation of Charles De Vis's claim that there is no change of fauna at higher elevations in North-East Queensland. ${ }^{53}$ Edmund Olive's younger brothers - Carlton C. Olive, Herbert L. Olive and John Henry ('Jack') Olive - also pursued an interest in naturalism, sending specimens to the Australian Museum and to private collectors. ${ }^{54}$ Their debt to their Aboriginal teachers, guides and companions, however, is not recorded in these collections.

\section{Conclusion}

E.A.C. Olive was both an author and agent of colonialism in the far north. He arrived in Cooktown during the Palmer River gold rush, when the frontier wars were at their height, 
and remained there during the period of consolidation of colonial rule, until his death in 1921. Cooktown is now a small and apparently insignificant township, but in the late nineteenth century it represented a key strategic outpost for Queensland's colonial government, for commerce and trade, and for natural science. E.A.C. Olive shaped his life around the opportunities provided by his location on the northern frontier: he made his fortune as a supplier of goods to miners and government officials during the initial invasion of Cape York Peninsula, held the influential administrative position of Shire Clerk for 36 years, built a thriving domestic economy on the use of Aboriginal labour, and was a prominent naturalist. In all of these spheres of activity, Olive and his family were dependent on Aboriginal people. Olive's wealth was based on the colonial government's forcible annexation of land, and consolidated through the use of Aboriginal labour, while his contributions to natural science owe much to the knowledge and skills of his Aboriginal guides, Billy and Sammy Olive. Since its founding, Cooktown has defined itself as a non-Aboriginal space, and emphasised the effort and enterprise of its immigrant 'pioneers' (mostly white, but also Chinese). This study of E.A.C. Olive contributes to dismantling that myth - a version of terra nullius - by demonstrating instead the ongoing dependence of Cooktown and its inhabitants on Aboriginal land and labour.

\section{Acknowledgements}

Pauline Grey, formerly Librarian of the Cooktown Library, has given me generous assistance with this research over a number of years, and commented on a draft of this paper.

Researchers and curators at various museums, including the Queensland Museum, the Australian Museum, and the Museum of Comparative Zoölogy at Harvard, have provided invaluable help with my research. I am grateful to Jeanette Covacevich, Senior Curator (Vertebrates) at the Queensland Museum, for her comments on a draft of this paper. Ian McKinna, Curator of the James Cook Historical Museum, kindly provided access to E.A.C. Olive’s letters.

${ }^{1}$ In 1986 the former Lutheran mission received a Deed of Grant in Trust (DOGIT) and formed the Hope Vale Aboriginal Council. In 1997, a Native Title determination was made for the lands covered by the Hope Vale Deed of Grant in Trust.

${ }^{2}$ W.J.L. Wharton, ed., Captain Cook's Journal during his First Voyage around the World, Made in H.M. Bark 'Endeavour' 1768-71 (Australiana Facsimile Editions, [London, 1893]; Adelaide: Libraries Board of South Australia, 1968), 289.

${ }^{3}$ Robert Logan Jack, Northmost Australia, 2 vols (London: Simpkin, Marshall, Hamilton, Kent, 1921), 375. A more northerly settlement, at Somerset, always precarious, was abandoned in 1877.

${ }^{4}$ Jack, 421-423.

${ }^{5}$ The Indigenous population in the Cooktown area in 1874 was substantial, as the climate and environment were very favourable: see Noel Loos, Invasion and Resistance: Aboriginal European Relations on the North Queensland Frontier 1861-1897 (Canberra: ANU Press, 1982), 3. See also Scott McKenzie, 'Our Lost Tribes', The Courier-Mail, 9 Jan. 1993: 8; an accompanying map by Norman Tindale suggests that the Cairns-Cooktown area may have been the most densely populated area in Queensland prior to white conquest.

${ }^{6}$ Cooktown Courier, 3 Feb. 1877; quoted in Loos, Invasion and Resistance, 71.

${ }^{7}$ Report of Commissioner for Police for 1875 in Henry Reynolds, ed., Aborigines and Settlers: The Australian Experience 1788-1939 (North Melbourne: Cassell, 1972), 12. See also Jean Farnfield, 'The Moving Frontier: Queensland and the Torres Strait', Lectures on North Queensland History (Townsville: History Department, James Cook University, 1974), 64.

${ }^{8}$ Edward Palmer, Early Days in North Queensland (1903; London: Angus and Robertson, 1983), 183. 
${ }^{9}$ Loos, Invasion and Resistance, 84. Loos records 147 deaths in 'Settlers and their Employees Reported Killed as a Result of Aboriginal Resistance in North Queensland Between 1861 and 1897: A Summary' in Invasion and Resistance, 189-247.

${ }^{10}$ Loos, 'Aboriginal Resistance on the Mining, Rainforest, and Fishing Frontiers', Lectures on North Queensland History, 163.

${ }^{11}$ Sir Raphael Cilento and Clem Lack Snr, Triumph in the Tropics: An Historical Sketch of Queensland (Brisbane: Smith and Paterson, 1959), 385. The lower estimate has been made by Pauline Grey, former Librarian of the Cooktown Library, on the basis of her detailed work on early records.

${ }^{12}$ The original Court House was removed many years ago to 18 Owen Street, Mossman, where it is now a private dwelling: it was once the home of Emma Bradford Olive (a daughter of E.A.C. Olive) and her husband Richard Hope. The Bank of North Queensland building is today owned by the Ferrari family and is used as a commercial premises; the former Bank of Queensland is currently a Westpac Bank, but its future is uncertain.

${ }^{13}$ Major-General [Reginald] Spencer Browne, A Journalist's Memories (Brisbane: Read Press, 1927), 46.

${ }^{14}$ A search of shipping records has failed to confirm the date of his arrival in the colonies, although he may be the Mr E.C. Olive who arrived on the Great Britain as an unassisted passenger in 1862: the age here is given as 'A[dult]' although E.A.C. Olive would in fact have been only 18. His son Edmund James Neil died of diphtheria in Mt Perry on 18 May 1873.

${ }^{15}$ Mabel Olive's birth was registered as no. 64 in the District of Cook.

${ }^{16}$ Information from Voters' Rolls, Cooktown.

${ }^{17}$ Glenville Pike, The Golden Days (Mareeba: Pinevale Publications, 1981), 63.

${ }^{18}$ Dorothy Jones, Trinity Phoenix: A History of Cairns and District (Cairns: Cairns Post, 1976), 103, 88, 144.

${ }^{19}$ The letters quoted are held by the James Cook Museum: drafts of business letters by E.A.C. Olive, in his own hand, were pasted into a foolscap ledger by Stanley H. Boyd in 1962; the condition of the letters is poor due to water damage and acidity.

${ }^{20}$ Spencer Browne, 51.

${ }^{21}$ The Colony of New South Wales Directory (Sydney: Government Printers Office, 1887). In the Directory, E.A.C. Olive is prominent in the various lists of trades and professions (as an accountant, auctioneer, insurance, customs and land agent, and produce dealer).

${ }^{22}$ Loos, Invasion and Resistance, 131; see also 118-159.

23 'Minutes of the First Meeting of the newly constituted Shire of Cook,' typescript by Nancy Keable, Cooktown, from the original manuscript. Olive's appointment was for 12 months, but by October 1919 he had stepped down from the position, probably following the death of his wife in June 1919. See also Cooktown Burial Register to 1920 and Monumental Inscriptions to 1986 (Cairns: Cairns and District Family Historical Society, ca 1989), np.

${ }^{24}$ G.C. Bolton, A Thousand Miles Away: A History of North Queensland to 1920 (Brisbane: Jacaranda Press, 1963), 170.

${ }^{25}$ Letter from a clergyman to the Anti-Slavery Society, 1883, quoted in Henry Reynolds, Frontier: Aborigines, Settlers and Land (Sydney: Allen and Unwin, 1987), 105.

${ }^{26}$ Garnet Agnew's watercolour painting of the view from Mt Olive is reproduced on the front cover of this issue of Queensland Review.

${ }^{27}$ 'Mount Olive: Peninsula Parklands', unidentified newspaper clipping, September [195?].

${ }^{28}$ Cec Murdoch, interviewed by Rosemary McKay, Cooktown, 23 Jun. 1990. Royce Lee, interviewed Cooktown, 23 Jul. 1995, recalled that Herbert L. Olive experimented with growing fruit such as oranges, mandarins, pomelos and coconuts on his farm near the Annan River.

${ }^{29}$ Interviews with Bob Cook, Cooktown, 1995 and 1997; Cec Murdoch; Royce Lee. Some of the original terraces remain, despite damage caused by bottle collectors after Herbert L. Olive left Cooktown due to ill health; some of the original plantings also survive.

${ }^{30}$ Interview with Neil Hope, Sydney, 25 Sep. 1992.

${ }^{31}$ Glenville Pike, Queen of the North: A Pictorial History of Cooktown and Cape York Peninsula (Mareeba: Glenville Pike, 1979), 107. Spencer Browne, 46, describes 'regatta' shirts and white drill slacks as fairly typical day wear for men in Cooktown's early years; Olive's attire, even for this formal 
photograph, was of a plain but distinctive design, somewhat resembling the informal dress of Chinese merchants in Cooktown (see, for example, the photograph of 'King' Shan in Pike, Queen of the North, 50).

${ }^{32}$ Grace (Olive) Worrall, interviewed by Rosemary McKay, Cooktown, 18 Jun. 1990; Duncan Jackson, interview with Eileen Kendall, 'An Oral History of Cape York Peninsula', typescript (Cooktown: Cook Shire Council, 1989), C-165 R-117, 4. Neil Hope, interviewed in Sydney on 25 Sep. 1992, said that his grandparents imposed strict rules about whom his daughters could speak to and dance with.

${ }^{33}$ Duncan Jackson, interview with Rene Hallam, 'An Oral History of Cape York Peninsula', C-168, R-117, 1. After Carlton C. Olive's death in 1958, Hans Looser discovered that tourists were stealing carvings from the empty Olive warehouse, and removed them for safekeeping. A reconstruction of the Joss House, containing many of the items salvaged by Carlton C. Olive, is now housed in the James Cook Museum, which was established in 1970. See also Barbara Toy, Columbus Was Right! Rover Around the World (London: John Murray, 1958), 191.

${ }^{34}$ Ion L. Idriess, The Tin Scratchers (1959; London: Angus and Robertson, 1980), 36.

${ }^{35}$ The Queenslander, 1 May 1880. The case of the so-called 'Normanby woman' reveals colonial attitudes to whites living with Aborigines (the situation of 'Nellie Olive' in reverse): in 1887 an elderly 'white' woman (probably albino) was 'rescued' with violence and against her will from the Aboriginal tribe with which she lived on the Normanby River, and she died soon after from injuries sustained in the process.

${ }^{36}$ Interview with Leffie Buhmann, Cooktown, 19 Jul. 1995. According to Buhmann, Sammy Olive's education protected him from being cheated of his wages when he worked as a tracker for the police.

${ }^{37}$ Interview with Guinevere Sacre, Sydney, 24 Sep. 1992; Leffie Buhmann; Neil Hope; Royce Lee; interview with Shirley McNamara, Sydney, Sep. 1992. Billy Olive's birth date is unknown; photographic evidence suggests that Sammy Olive was born in the early 1900s.

${ }^{38}$ Cec Murdoch, interviewed by Rosemary McKay, Cooktown, 23 Jun. 1990. Cec Murdoch arrived in Cooktown as a cane cutter in 1932; his account of life at Mt Olive is based largely on what he was told by his employer, Herbert L. Olive.

${ }^{39}$ Rosemary McKay, ms notes of conversations with Dorothy (Norbury) Adams.

${ }^{40}$ Neil Hope's aunt, Grace (Olive) Norbury, told him that E.A.C. Olive's thwarted the removal of Billy and Sammy Olive (Neil Hope, telephone interview, 16 Jul. 1995).

${ }^{41}$ Rosalind Kidd, The Way We Civilize (St Lucia: University of Queensland Press, 1997), 355 n. 1.

${ }^{42}$ Neil Hope, 16 Jul. 1995, recalled that in the 1930s the camp was at the foot of Mt Olive. Aboriginal elder, Jack Harrigan, indicated the same spot to Pauline Grey, commenting that the Mt Olive camp was out of sight of the road and therefore could be ignored by white townspeople. Neil Hope's recollections suggest that this camp was a ceremonial centre, which Henry Reynolds has claimed was not uncommon for town camps: see 'Townspeople and Fringe-Dwellers', Race Relations in North Queensland, ed. Henry Reynolds (Townsville: History Department, James Cook University, 1978), 169.

${ }^{43}$ Bulletin of the British Ornithologists' Club, 10.69 (1900): xliv.

${ }^{44}$ Herbert C. Robinson and W.S. Laverock, with field-notes by E. Olive, 'The Birds of North Queensland', The Ibis: A Quarterly Journal of Ornithology, Seventh Series, 6 (1900): 618.

${ }^{45}$ Telephone interview with Guinevere Sacre, 12 Aug. 1992.

${ }^{46}$ Jack, vol. 2, 403-404.

${ }^{47}$ E.A.C. Olive to Echlin [probably Gawne Echlin], 29 Sep. 1882 (held James Cook Museum). The official name for Queensland's floral emblem is Dendrobium bigibbum var. phalaenopsis, but there is debate over the correct botanical name of the Cooktown Orchid. Dendrobium phalaenopsis (Fitzgerald, 1880) is sometimes identified with Dendrobium bigibbum (Lindley, 1850), but the Australian National Botanic Gardens considers them to be separate species, with Dendrobium phalaenopsis occuring naturally between Johnston River and Iron Range, and Dendrobium bigibbum further north.

${ }^{48}$ Alfred J. North, Nests and Eggs of Birds Found Breeding in Australia and Tasmania, Special Catalogue No. 1, Part II, $2^{\text {nd }}$ edn (Sydney: Australian Museum, 1902), 57. According to his grandson, Neil Hope, Olive - as a point of honour - shot only birds 'on the wing'. The Eastern Bower-Bird (Chlamydodera orientalis) was distinguished by Gould from the Great Bower-Bird (Chlamydodera nuchalis) in 1879 due to some small differences: the former is now regarded as a variation of the latter. In the nineteenth century, the desire to discover new species led to a plethora of classifications which have since been reduced.

${ }^{49}$ North, 117. 
${ }^{50}$ North, 65. See also Graham Pizzey, The Field Guide to the Birds of Australia (Pymble, NSW: HarperCollins, 1997), 478.

${ }^{51}$ Gymnodactylus olivii Garman, 1901 is a junior synonym of Cyrtodactylus louisiadensis (De Vis, 1892). See Samuel Garman, 'Some Reptiles and Batrachians from Australasia', Bulletin of the Museum of Comparative Zoölogy at Harvard College, 39 (1901): 1-14: E.A.C. Olive donated 'a large number' of specimens of reptiles to Garman.

${ }^{52}$ Turnix olivii was classified by Herbert C. Robinson: see Bulletin of the British Ornithologists' Club, 10.69 (1900): xliii-xliv. For a period, it was regarded as a junior synonym of Turnix castanota (Gould, 1840) but has been reinstated as a separate species. Lloyd Nielsen recently investigated the present status of this rare bird with a grant from the Queensland Ornithological Society. Nielsen, in a telephone interview on 11 Aug. 2000, stated that Turnix olivii is certainly a distinct species, and that it is even rarer than previously thought. On the basis of Nielsen's project, Turnix olivii is considered an endangered species.

${ }^{53}$ Robinson and Laverock, 617-649. Edmund Olive and his father are sometimes confused in museum collections, and also in Hubert Massey Whittell, The Literature of Australian Birds: A History and a Bibliography of Australian Ornithology (Perth: Paterson Brokensha, 1954), 568. I am grateful to Jeanette Covacevich of the Queensland Museum for drawing my attention to Whittell's incorrect entry, which is headed E.A.C. Olive, but describes the activities of Edmund Olive.

${ }^{54}$ The Australian Museum holds specimens obtained directly from the Olives, as well indirectly via other collections. According to Walter Boles of the Division of Vertebrate Zoology (Birds) at the Australian Museum, the latter includes ornithological specimens obtained through the collections of Thomas Austin, William Macgillivray and the Bettington family-Lindsey Hyem. Carlton C. Olive's assistance is acknowledged by L.J. Brass, leader of the 1948 Archbold Expedition to Cape York: L.J. Brass, 'Results of the Archbold Expeditions. No. 68: Summary of the Cape York (Australia) Expedition', Bulletin of the American Museum of Natural History, Vol. 102, Article 2 (1953): 142. 